can be made thereby zero for any particular latitude in one hemisphere only. There is a second correction due to the ship's motion in latitude, small and independent of the particular instrument, and there is a third correction, a ballistic correction due to change in the ship's motion in latitude. Space does not admit of these being followed out, but they are fully explained.

The directive force of the gyrostatic compass is about fifteen times as great as that of an ordinary magnetic compass undisturbed by surrounding iron. In addition, therefore, to its being undisturbed by the magnetism of the ship or the movements of heavy magnetic pieces, such as guns, a master gyrostatic compass may be set up in a protected and quiet spot low down in the ship, and there control a number of dials placed in convenient positions for steering or for taking azimuth observations. These local dials are provided with central dials geared up thirty-six times, so that a complete turn corresponds to ten degrees. With such a compass to steer by and steering

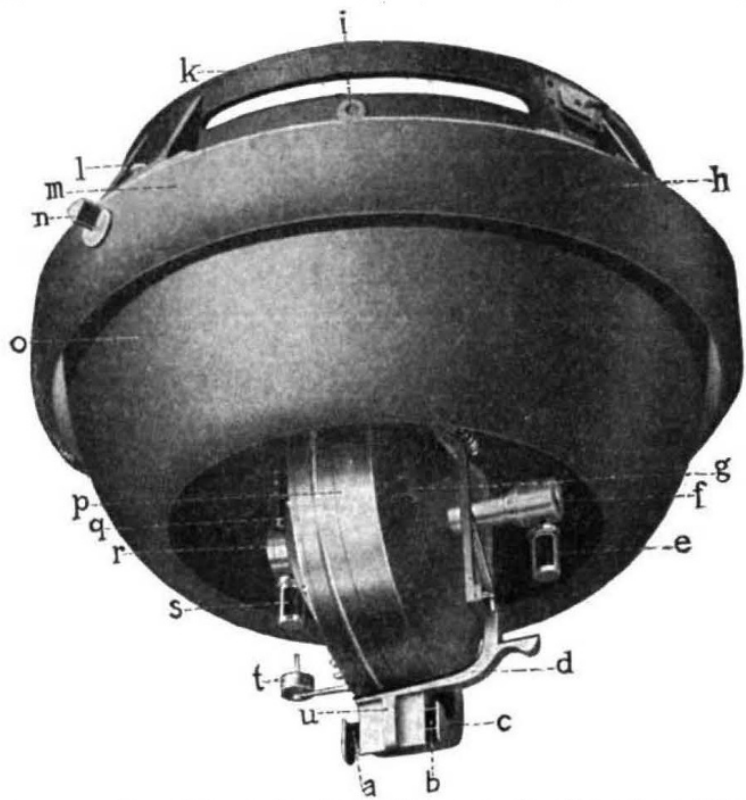

FIG. 2.- $a, b$, variable outlets for air blast ; $c$, outlet pipe; $d$, pendulum arm ; $e, s$, oil cup for gyro bearings ; $f, r$, gyro bearings; $g$, inlet opening for air ; $q$, terminal of gyro notor; $p$, gyro case ; $o$, mercury bowl.

gear of greater precision than usual, the new compass should effect a saving in the actual distance run and in the horsepower at present wasted on the rudder, and it is an interesting question how long it will take for the reduction in the coal bill to pay for the compass.

It is not possible owing to limitations of space to follow the numerous details relating to the theory, construction, and use of this beautiful instrument, but anyone with a sense of fine mechanics will appreciate this excellent exposition, even though he may never have the chance of running the compass himself.

C. V. Boys.

\section{THE PRESERVATION OF ANCIENT}

\section{$M O N U M E N T S$}

$\mathrm{T} \mathrm{HE}$ report of the Inspector of Ancient Monuments for the year ending March 3I, I9I I, is the first by the new inspector, Mr. C. R. Peers. There are I04 monuments under the care of the Commissioners of Works, forty-eight in England and Wales and fifty-seven in Scotland. During the last year fifteen monuments have been placed under No. 2 I77, VOL. 87$]$ the protection of the Ancient Monuments Acts, ten in England and Wales and five in Scotland. Eight of the newly-protected monuments are situate in Anglesey, all prehistoric monuments, three of which have recently been astronomically surveyed by Sir Norman Lockyer and others. Of the two prehistoric Orkney monuments now under protection, the Chambered Mound of Maeshowe has received the attention of the same authority.

Useful linear measures are given of the monuments noticed in the report, and in one case, as a sort of nest-egg, we have the information that the bearing of the dolmen at Trefigneth "comes within one degree of the line of the winter solstice." Never a word is found referring to the available astronomical surveys, while it may safely be asserted that the formal protection of the Anglesey and Maeshowe monuments is largely due to the local interest awakened in the astronomical inquiry. In connection with the statement that "no adequate record has up to the present time been kept of the treatment of each monument year by year," surely the annual reports issued by the Pembrokeshire archæologists should have been mentioned.

"Certain observations of a general character" are most timely and important. "The first Ancient Monuments Act has now been in operation for twenty-nine years. Of the fifty-one prehistoric monuments scheduled by it as worthy of preservation by the State, twenty-six have been placed under its provisions, by the consent of the owners, while the rest, for various reasons, have not been so placed. In regard to these latter, the position of the State is entirely unsatisfactory, and these monuments are in a worse case than if they had not been noticed in the Act." The second Act of I 900 has a wider scope, with the grand result that we have now three castles and three monastic buildings added to the State waifs and strays! This report, like others of its kind, reveals the deplorable ineffectiveness of high-sounding measures. It also shows that where a scientific survey of a monument is first made and the results dulv published, owners of such properties are among the first to recognise the necessity for effective protection. Lord Boston, Lord Sheffield, and Major Fox-Pitt have nobly led the way in Anglesey. The first and foremost factor in the case is scientific inspection, and monuments are best preserved in accurate measures.

JoHn GRIFFITH.

\section{THE PORTSMOUTH MEETING OF THE BRITISH ASSOCIATION.}

I $\mathrm{N}$ about six weeks' time, on August 30 , the citizens of Portsmouth will have the privilege of welcoming the members of the British Association for their annual meeting. In many respects this meeting will be a contrast to that at Sheffield last year. Portsmouth cannot offer the attractions of large engineering works or manufactories, but at the same time it holds a unique position as the first naval port of the United Kingdom, and one of the most ancient of its boroughs. The borough of Portsmouth fifty or sixty years ago included only a small portion of the island of Portsea, on which the town is situated. There were walls and gates (which were closed every day at sunset) and a military governor. The walls are gone, but some of the old parts of the town are still well worth a visit. Three years ago the borough boundary was enlarged, now including the whole of the Island of Portsea.

Opportunity will be offered to members of the British Association to inspect the old corporation plate dating from Queen Elizabeth onward, and the old charters of the town, covering the last 500 years, can 